\title{
局在プラズモンを利用した単一分子ラマン観察
}

\author{
二又 政之 ${ }^{1}$ ，丸山 芳弘 ${ }^{2}$ \\ 1産業技術総合研究所 (テ305-8562 茨城県つくば市東1-1-1中央4) \\ 2浜松ホトニクス (株) 筑波研究所 (テ300-2635 茨城県つくば市東光台5-9-2)
}

\section{Single Molecule Characterization with Raman Scattering Using Localized Surface Plasmon}

\author{
Masayuki FUTAMATA ${ }^{1}$ and Yoshihiro MARUYAMA ${ }^{2}$ \\ ${ }^{I}$ National Institute of Advanced Industrial Science and Technology (AIST), Central 4, 1-1-1 Higashi, Tsukuba, Ibaraki 305-8562 \\ ${ }^{2}$ Tsukuba Research Laboratory, Hamamatsu Photonics K.K., 5-9-2 Tokodai, Tsukuba, Ibaraki 300-2635
}

(Received September 5, 2005)

\begin{abstract}
Enormous SERS (Surface Enhanced Raman Scattering) signal from dye on hot or blinking silver nanoparticles is extinguished by duration of measurement possibly due to thermal diffusion or desorption of adsorbed molecules. Simultaneously, elastic scattering peak at ca. $630 \mathrm{~nm}$ disappeared. Three-dimensional Finite Difference Time Domain (FDTD-3D) method manifests this scattering peak originates from enhanced coupling of localized surface plasmon (LSP) on adjacent Ag particles through absorption of adspecies located at their junction. Distinct emission peaks were observed at 550-600 $\mathrm{nm}$ and $600-750 \mathrm{~nm}$. Based on the spectral variations for different surface coverage and for different dye species, the shorter and longer wavelength peaks were attributed to excited electron on metal, and from fluorescence of molecules, respectively. Furthermore, we found the shorter wavelength peak shows invariant Stokes shift irrespective of excitation wavelengths, indicating it arises from inelastic scattering of excited electron by surface roughness or by adsorbed molecules.
\end{abstract}

Key Words: Localized surface plasmon, Surface enhanced Raman scattering, Single molecule detection

\section{1.はじめに}

固液界面にin situで適用できるラマン分光法では，分子 の存在状態 (構造・配向性 ·周囲の化学種との相互作用)に ついての情報が得られる。このため，ナノ材料分析，触 媒反応解析, グルコースセンサなどバイオ系の高感度分 析などに幅広く適用されている。しかし，もともと単一 分子感度を有する蛍光分光と比べて, 古典的なラマン分 光法では散乱断面積はおよそ10-14も小さく, 微量分析は一 般に困難である。そのために30年ほど前から知られてい る「粗い金属表面に吸着した化学種のラマン散乱が $10^{4}-10^{6}$ 倍増強する」という表面増強ラマン効果 (Surface Enhanced Raman Scattering, SERS) ${ }^{1,2}$ )が利用されている. 増強メ力 ニズムとしては，(1)金属の局在表面プラズモン (Localized Surface Plasmon, LSP)が入射光により励起されたときに形 成される巨大な電場(電磁気学的増強), 及び(2)金属表面と 吸着種との間の電子移動相互作用による共鳴効果 (化学的 増強)が指摘されている。どちらのメカニズムでも，金属 表面形状にラマン散乱の増強度が大きく依存する。従来 は，いろいろな形状やサイズの粗さを持つ金属表面や金 属粒子からの信号を統計平均として検出していたが, 最 近の走査型プローブ顕微鏡やCCDなどの高感度光検出器
の発達により，最適な形状を有する粒子のみからの信号 を検出することで，単一分子検出が現実的になってき た3-7). ただし, 逆説的であるが単一分子感度ラマン分光 法の確立は，(1)金属ナノ構造表面に1個の分子が吸着して いることを直接証明する方法がないこと，あるいは(2)実 験的な不安定さ，繰り返し測定の困難さなどから容易な 仕事ではない。ここでは，我々のグループで最近得られ た結果を中心に将来展望を含めて解説する7-14).

\section{2. 単一分子感度ラマンのための接合部の重要性}

2.1 Blinking とそのオリジン

Fig. 1に単一分子感度ラマン分光のための顕微鏡・レー ザー・白色光源・CCDカメラ・ポリクロメータからなる 測定装置を示す。一般に化学還元法で調製された種々の 形状・サイズを持つ金属ナノ粒子が，ガラスやシリコン 表面に固定され, SERS基板として用いられている. 形成 された粒子は塩化物イオンで表面を置換したのち, カチ オン性色素などを静電的に吸着させて試料とする．色素 分子がよく用いられる理由は, 可視部に電子吸収を持つ ために励起光による共鳴効果を利用することで, 他の一 般的な分子に比べて $10^{4}$ 程度の付加的な増強が得られるか 


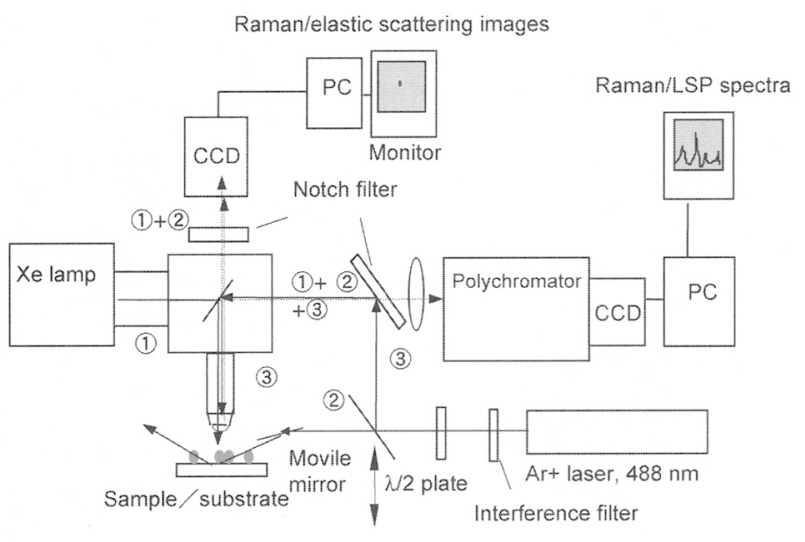

Fig. 1 Facility for single molecule Raman spectroscopy Elastic scattering image or spectra of the R6G/Ag nanoparticles were measured with a Xe lamp, CCD camera and polychromator. Raman images and spectra were measured using $\mathrm{Ar}^{+}$laser under external or back scattering geometries.

らである。レーザー光は, 外部反射 (Fig. 1(2))または対物 レンズを通した後方散乱配置(同(3))で試料に照射され，顕 微鏡上のCCDカメラによりラマンイメージ，または分光 器 (Polychromator) 老通してラマンスペクトルが測定され る。同様にしてXeランプなどの白色光の暗視野照明(1) により弾性散乱イメージ及びそのスペクトルが得られ る。試料基板上のマーカーを利用して，個々の金属ナ， 粒子の分光特性と AFM (原子間力顕微鏡)によるナノス ケールの構造とが対応づけられる。このとき, 金属ナノ 粒子1個あたりの吸着色素分子数を下げていくと，多くの 粒子のうちごく一部が強いSERS信号を与えることがわか る (Fig. 2(b)及び2 (a)，(c)，(d)の矢印)。これらのhot particleは，いずれも金属ナノ粒子接合体であり，接合軸に平 行な偏光を照射したときのみ巨大なSERS信号を与える。 また, 被覆率が数10分子/ナノ粒子以下になると, 信号強 度が時間的に摇動する現象 (Blinking) が観測される3-7)。こ れは，(1)完全なON/OFF特性を示すこと3)，(2)強度がPoisson分布 (一定強度とその整数倍の信号がPoisson分布を 持ってあらわれる)を示すことなどから ${ }^{4)}$, 単一分子現象

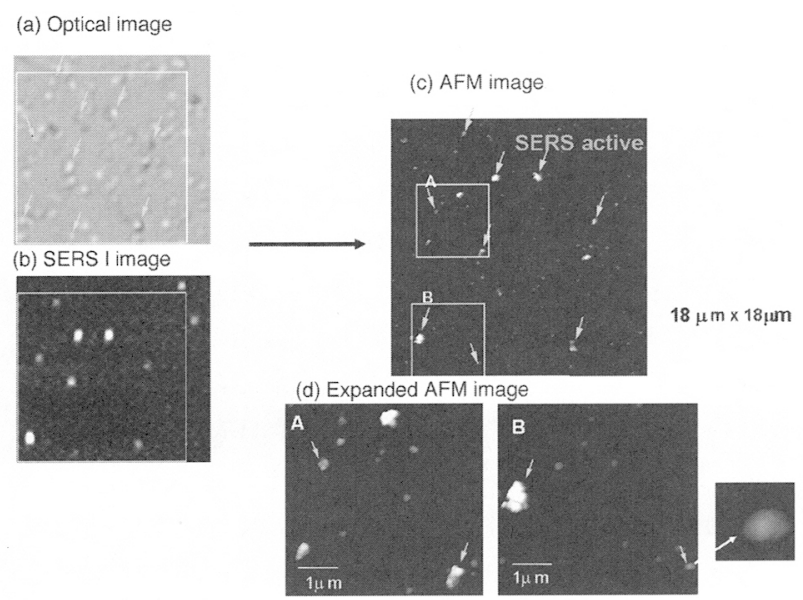

Fig. 2 Optical image (a), Raman image (b) and AFM images (c, d) of Ag nanoparticles. Hot particles providing enormous SERS signal are denoted by the arrow.
の証拠と考えられている。このBlinkingのオリジンとして は，光刺激脱離一再吸着といった特定の金属と吸着種の 間でのみ可能な光励起メカニズムが挙げられた ${ }^{16)}$ 。しか し，同様の現象が色素だけでなく可視部に吸収のない DNA塩基でも観測されている7,13)。これに関して，我々は 温度依存性の実験を行いBlinkingが熱活性化過程であるこ とを確かめた8)。すなわち，室温でSERS信号強度が摇動

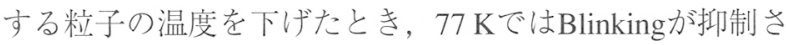
れ，測定の間中つ称に強い信号を与えるか，反対に全く 信号を与えない場合が観測された。再び室温に戻すとこ れらの粒子のBlinkingは回復する (Fig. 3)。こうした銀ナ) 粒子にレーザー光を照射したときに形成される局所電場 をFDTD (Finite Difference Time Domain)数值計算法17)によ り解析した (銀の誘電率は実測值 ${ }^{20}$ )を用い, 銀ナノ粒子は 半径 $40 \mathrm{~nm}$ の無限円筒または一辺 $80 \times 80 \mathrm{~nm}$ の直角二等辺 三角柱。半径 $40 \mathrm{~nm}$ の球状粒子や有限高さの三角柱を用い た3次元計算でも，ほぼ同様の結果が得られた)。その結 果，近接銀ナノ粒子のin-phase LSPを軸に平行な偏光で励 起することで，接合部に入射光の $10^{5}-10^{6}$ 倍もの巨大な電 場 (これにより単一分子感度に相当する $10^{10}-10^{11}$ のラマン 増強が得られる)が形成されることが判明した(Fig. 4, 励 起波長は最大強度を与える(a) $430 \mathrm{~nm}$, (b) $480 \mathrm{~nm}$ )。接合 部以外の銀ナノ粒子表面では，孤立粒子と同様にそれに 比べて小さな $10^{2}-10^{3} の$ 電場増強しか得られない。このこ とから，一般的な吸着分子について，接合部とそうでな いサイトの間での熱拡散メカニズムがSERS信号のBlinking を与えているものと考えられる8,11,13).

\section{2 弾性散乱に現れる単一分子吸着の証拠}

Fig. 5 (d)に示す銀ナノ粒子接合体は強いラマン信号 (増 強度 $10^{8}-10^{9}$ ，Fig. 5 (a) 老与える。同時に白色光を用いて 弾性散乱を測定すると，LSPによるブロードな散乱ピーク

(a) RT: Blinking $\rightarrow \quad$ (b) $77 \mathrm{~K}$ : Invariant bright spot $\rightarrow$ (c) RT: Blinking after warme

33 flame $/ 2 \mathrm{sec}$

(d)

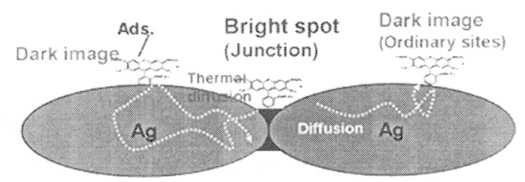

Fig. 3 Temperature dependence of blinking: (a) at room temperature, (b) at $77 \mathrm{~K}$ and (c) RT after warmed. All the images were obtained with a CCD camera at a video rate (33 flames/sec). (d) Schematic images of thermal diffusion of adsorbed molecules between junction and marginal region on touching $\mathrm{Ag}$ nanoparticles. 
(a) Edge of Ag nanoprism

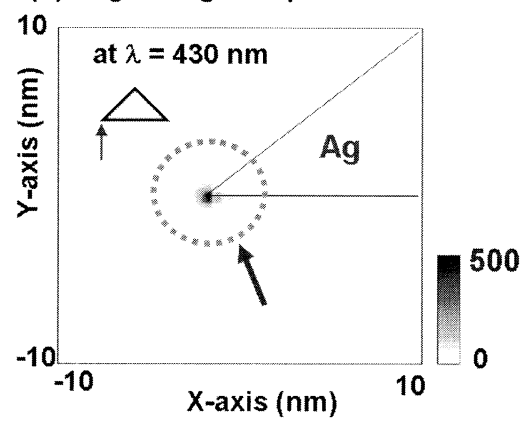

(b) Junction of touching $\mathrm{Ag}$ nanoparticles

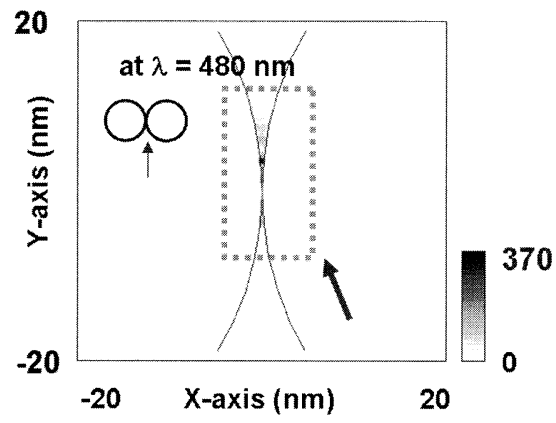

Fig. 4 Local field intensity obtained with FDTD numerical simulations: (a) at the sharp edge, (b) junction of touching Ag nanoparticles (spheres with a radii of $40 \mathrm{~nm}$ ). Single molecule sensitivity is predicted at these positions.

$(525 \mathrm{~nm}, 730 \mathrm{~nm})$ とともに，630 nmに付加的なピークが 観測される (Fig. 5 (b)，（d））。しかも630 nmの散乱は, SERS活性と強い相関があり, 時間が経過して吸着分子の 拡散などにより，ラマン信号が失われるとともに消失す る.このような現象は，ごく微量の色素やDNA塩基のア デニンが吸着した銀ナノ粒子接合体に共通して観測され る. 付加的な散乱ピークは，近接する銀ナノ粒子のLSPが 接合部に吸着する微量分子の電子遷移と相互作用するこ とにより生じたものであることが，FDTD-3D数值計算に より明らかになった ${ }^{9,12)}$. Fig. 6に示すように，球状銀粒子 (半径40 nm, ギャップ4 nm) の接合部に吸着分子 $(4 \times 4 \times 4$ $\mathrm{nm}^{3}$ ，ローダミンの実測吸収スペクトル減衰振動子モデル で表したときの誘電率を使用)を配置し，接合軸に平行な 偏光を入射したとき，散乱スペクトル $370 \mathrm{~nm}$ (2粒子のLSP のout-of-phaseモード) と470 nm(in-phaseモード)の2つの LSPピークとともに，長波長側 $(750 \mathrm{~nm})$ にそれらよりは弱 いが明確なピークを与える。この付加的な散乱ピーク は，(1)吸収のない化学種(水分子やガラス基板など)を接合 部においても現れないこと，(2)吸着種の吸収波長を650 $\mathrm{nm}$ から $260 \mathrm{~nm}$ に変えたとき，対応して散乱ピーク波長が $750 \mathrm{~nm}$ から420 nmにシフトすること(Fig. 7(a)-(b)，(3)吸 着種の振動子強度を変えたとき，それに対応してピーク 強度が変化すること(Fig. 7(c)) などから, 明らかに吸着種 の吸収に起因するものである14)。詳細な波長依存性か ら, LSP と吸着種の吸収の間で電磁気学的相互作用が存在 することが確かめられた。

さらに興味深いことに，このような相互作用が存在す
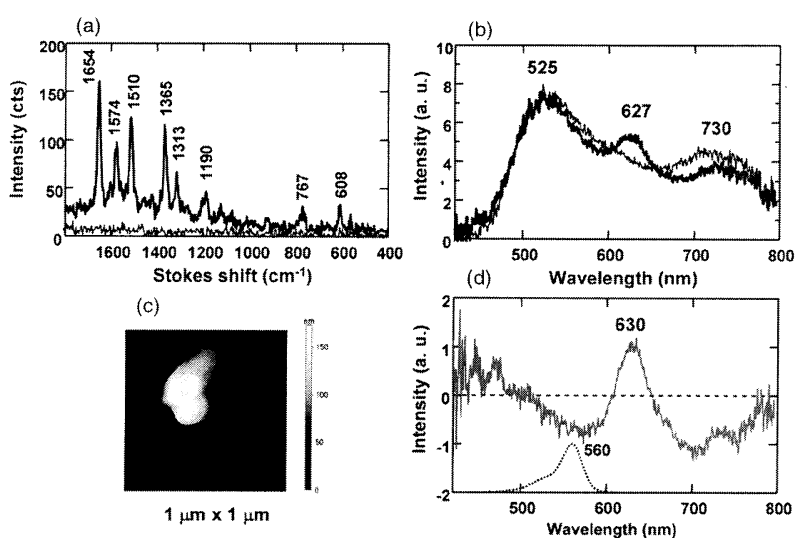

Fig. 5 Correlation between SERS and elastic scattering from R6G/Ag nanoparticles: (a) SERS, (b) elastic scattering spectra, (c) AFM image and (d) difference spectra between SERS active and inactive state. The additional elastic scat-tering peak is obtained only for SERS-active state.
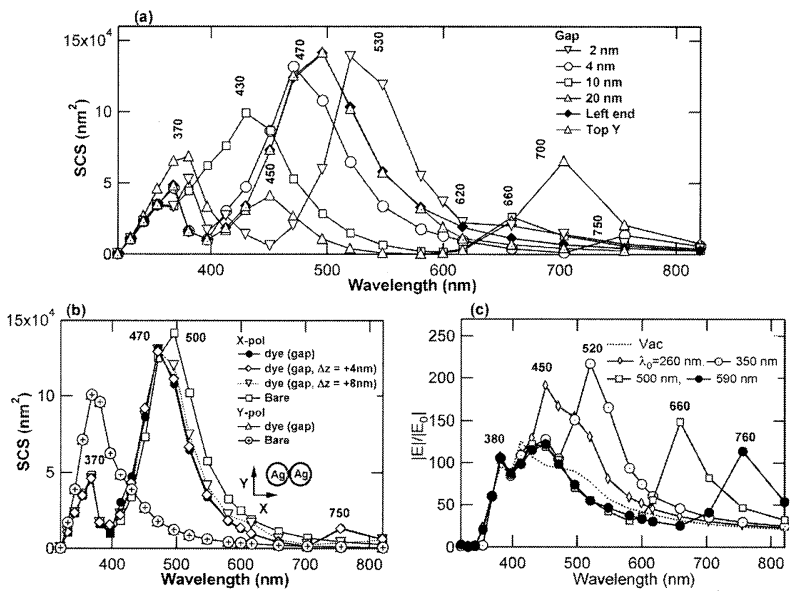

Fig. 6 Elastic scattering spectra calculated for adjacent $\mathrm{Ag}$ nanoparticles (radii of $40 \mathrm{~nm}$ ) with FDTD method: (a) for various gap sizes filled with R6G, (b) for different polarization of incident laser and for different positions of adsorbates (with the fixed gap size of 4 $\mathrm{nm})$, (c) local electric field for the same sample system as in (b) with different absorption peak.

るとき $420 \mathrm{~nm}$ 付近のLSP共鳴とは別に, 弾性散乱のピーク 波長において，接合部に付加的に増強された電場が形成 される (Fig. 6(c)の450，520，660，760 nmのピーク，Fig. 8). これまでの単一分子感度に関する金属ナノ粒子系の 電場計算では，吸着分子をおかずに局所電場強度を計算 し，散乱過程であることから，その二乗によりラマン増 強度が見積もられてきた。しかし，実際の系では，特に 励起波長に近い電子遷移を持つ分子系では，増強電場は 吸収のために大きく減衰する。例えば，Fig. 8(a)に示すよ うに, LSP共鳴波長でも, 接合部に存在する吸着分子内部 の電場は，近接する外側に比べて著しく小さい.すなわ ち，吸着種を置かない金属ナノ粒子系での電場増強の見 積もりは大きすぎる。ところが，同じ試料系でも，付加 的な散乱ピークや増強吸収ピーク波長では, 吸着分子内 部に大きな増強電場が形成されることが判明した(Fig. 8 (b)).おそらくこれは，近接する銀ナノ粒子のLSPがこの 

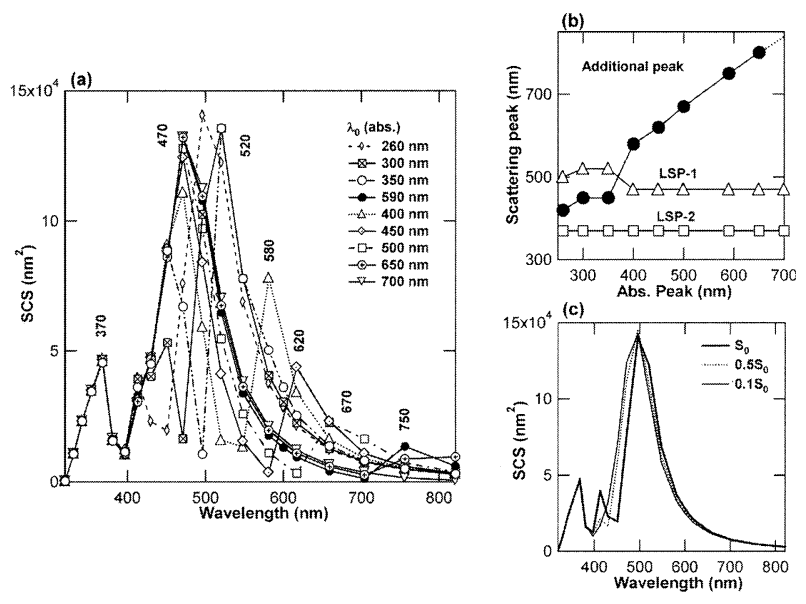

Fig. 7 Elastic scattering spectra calculated for adjacent $\mathrm{Ag}$ nanoparticles (radii of $40 \mathrm{~nm}$ ) with FDTD method: (a) correlation between peak wavelengths of absorption of dye and additional elastic scattering, (b) summary of (a), (c) peak intensity vs. oscillator strength of absorption of dye at $350 \mathrm{~nm}$.

波長で分子を通して大きなカップリングを持つためであ ろうと考えられる19).

\section{3 特異的な発光スペクトル}

SERS研究の初期から, 強いSERS信号のバックグラウン ドとして非弾性散乱が観測されることが知られてい る ${ }^{1,2)}$. このオリジンとしては, 吸着種の発光, LSPの輻射
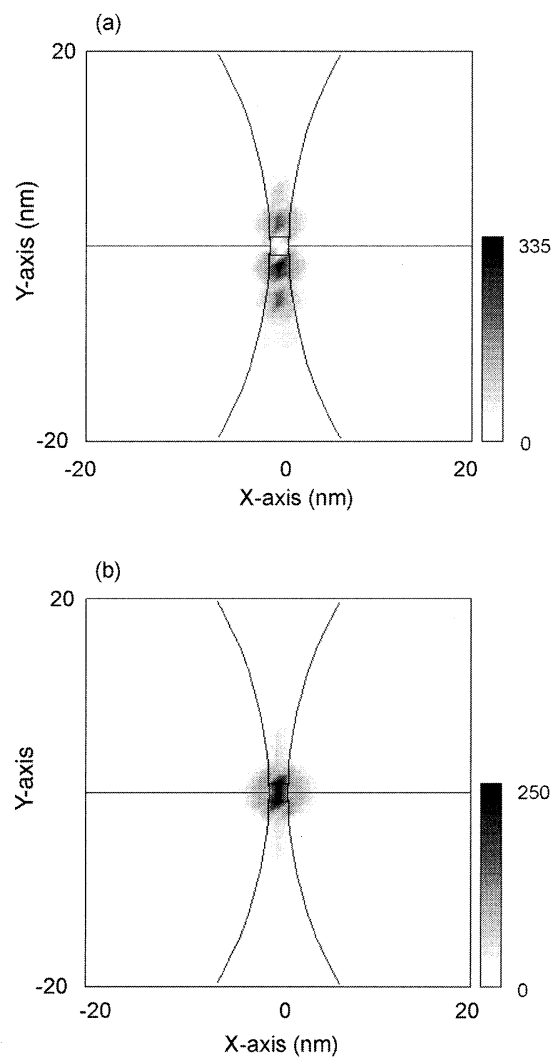

Fig. 8 Local field distribution for R6G/Ag nanoparticles with radii of $40 \mathrm{~nm}$ and gap of $4 \mathrm{~nm}$ : (a) $l_{\mathrm{ex}}=410 \mathrm{~nm}$ (LSP resonance), (b) $1_{\mathrm{ex}}=760 \mathrm{~nm}$ (additional peak position).
緩和, 金属酸化物の励起子, 金属ナノクラス夕の発光, 金属表面の電子ラマン散乱などが挙げられているが，明 確な結論には至っていない1,2,10,14,15). 最近の研究により, 形状やサイズ·集合状態を特定した個々の金属ナノ粒子か らのスペクトル測定が行われ，より詳細な議論が可能と なってきた，我々は，吸着色素の種類と被覆率を変える ことで，色素の発光と金属表面からの非弾性散乱を区別 することに成功した10,14,15)。例えば，Fig. 9は異なる被覆 率のR6G（ローダミン 6G，a: 3分子/粒子，b: 30分子/粒 子)，異なる色素CV (クリスタルバイオレット，c:30分子/ 粒子)，MG(マラカイトグリーン，d：300分子/粒子)の SERS と同時に観測される発光スペクトルである(励起波長 $488 \mathrm{~nm})$.ここで，長波長側の620-710 nmにピークを持つ 発光は, (1)色素の種類によりピーク波長が変化し, かつ 吸着量とともに発光強度が増加すること, 及び(2)ガラス 基板に直接調製した色素の吸収及び蛍光スペクトルとよ く一致することから，銀ナノ粒子表面で増強された色素 の蛍光と帰属される。一方，短波長側に観測される550$600 \mathrm{~nm}$ のピーク波長·強度は色素に依存せず，ほぼ一定の 波長と強度を示すことから，金属表面の電子状態に由来 する発光と考えられる10).

興味深いことに，励起波長を514.5 nmに変えたとき， $\mathrm{R} 6 \mathrm{G} /$ 銀ナノ粒子について観測された短波長側のピーク は，488 nm励起のときと同じ $3000 \mathrm{~cm}^{-1}$ のストークスシフ 卜（励起波長からの波数シフト)を示すことが判明した (Fig. 10) ${ }^{15)}$ 。これは，同じ粒子について励起波長のみを変 えた実験で得られた結果であり，かつ別の粒子について も同様の発光特性が得られた14). 対照的に，(当然である が)長波長側の発光は，上記と同様に励起波長によらず一 定のピーク波長を与える。また，短波長側のストークス シフトは，色素を $\mathrm{CV}, \mathrm{MG}$ と変えたときR6Gとほぼ同様に $2625 \mathrm{~cm}^{-1}, 2850 \mathrm{~cm}^{-1}$ 付近に観測される。この金属表面に 由来する非弾性散乱は，励起波長によらず一定のストー
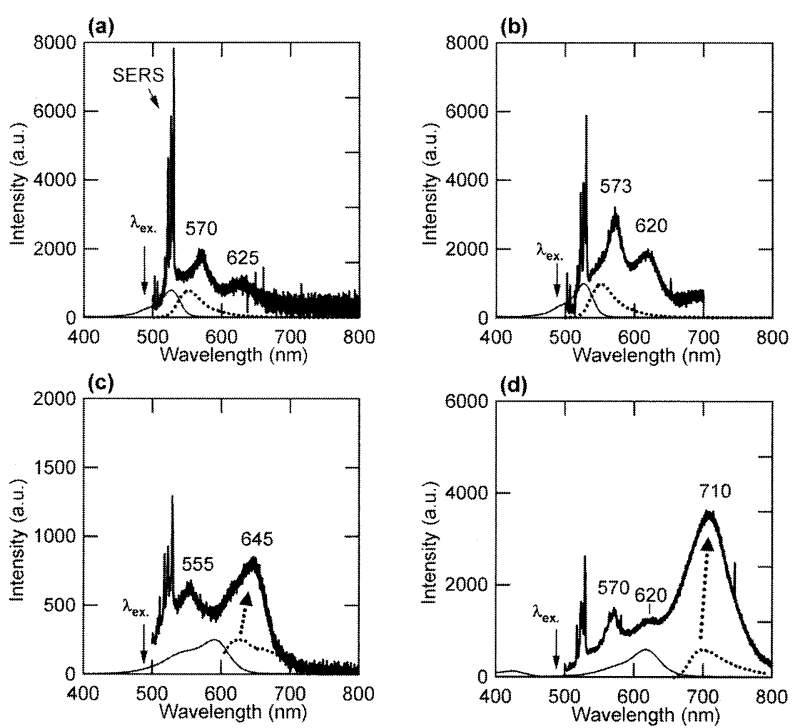

Fig. 9 Emission spectra: (a) R6G (3 molecules/Ag particle), (b) R6G (30 molecules/Ag particle/), (c) CV (30 molecules/Ag particle), (d) MG (300 molecules/Ag particle). 

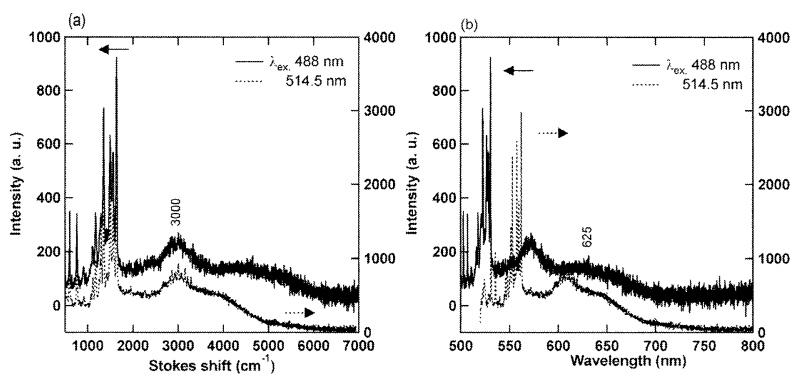

Fig. 10 SERS and emission spectra measured for the same Ag nanoparticles/R6G with different excitation wavelength (488 $\mathrm{nm}$ and $514.5 \mathrm{~nm}$ ): (a) in Stokes shift, (b) in wavelength.

クスシフトを持つことから, LSPの輻射緩和や金属酸化物 の励起子緩和，金属クラス夕，色素の蛍光のいずれでも ない。これらの場合，ずっと大きなエネルギーを持った 発光が，一定のピーク波長を持って放射されるはずであ る. 唯一可能性として考えられるのは, 金属表面の電子 ラマン散乱によるものである。これは以前Ottoらが超高真 空下，低温で蒸着した銅や銀表面で吸着種なしでも観測 した非弾性散乱によく類似している18)。彼らは，それを 金属表面で励起された電子が原子レベルの粗さのために 非弾性的な散乱を受けることで, 結果的に基底状態の フェルミ面付近に電子-格子対が形成されるものとして説 明した．同時に，金属薄膜を加熱したときに観測される スペクトル変化を, 表面電子の分散曲線が変化するとし て再現した。 これに対して, 我々の非弾性散乱は, 色素 などの分子を吸着した巨大SERS活性を有する銀ナノ粒子 についてのみ観測されるものであり, SERS活性のない粒 子や，吸着種のない粒子では全く観測されない.このこ とは，金属電子が表面粗さや欠陥と同様に，吸着分子に よって非弾性的に散乱されることを示唆している。ここ で用いた銀ナノ粒子は，化学還元法で調製する際に $100{ }^{\circ} \mathrm{C}$ で約1時間アニールしているために，原子レベルの粗さは 存在せず，(111) facet面が独占的に形成されており6), 吸 着種の存在により初めて非弾性散乱が起こるものと考え られる。さらに, 通常の共鳴ラマン散乱とは異なり, $3000 \mathrm{~cm}^{-1}$ 領域にR6Gの高次モード(結合音や倍音)が極めて 強く観測されている (Fig. 11). 非弾性散乱とこれらの高次 項の強度の相関について現在検討中である.

\section{3. 今後の展望}

単一分子感度ラマン分光法が確立され，実用化される ためには，上記のような基本的な点の解明とともに，(1) 形状とサイズの決まった金属ナノ粒子をAFMなどで操作 し，それらのギャップサイズを制御した上で，励起波長・ 入射方向 ·偏光方向などを変えながら吸着種のSERS信号 の詳細な測定及び吸着種を含めたFDTD法などによる電場 強度の解析を行うこと, (2)空間分解能を極限まで上げた 近接場分光法により, 金属ナノ粒子表面の局所的な電子 状態・SERSスペクトル測定することで, LSPによる電場 の空間分布の解析を行い, 理論計算との比較から最適形 状を見出すこと, (3)色素やDNA塩基以外のさまざまな吸

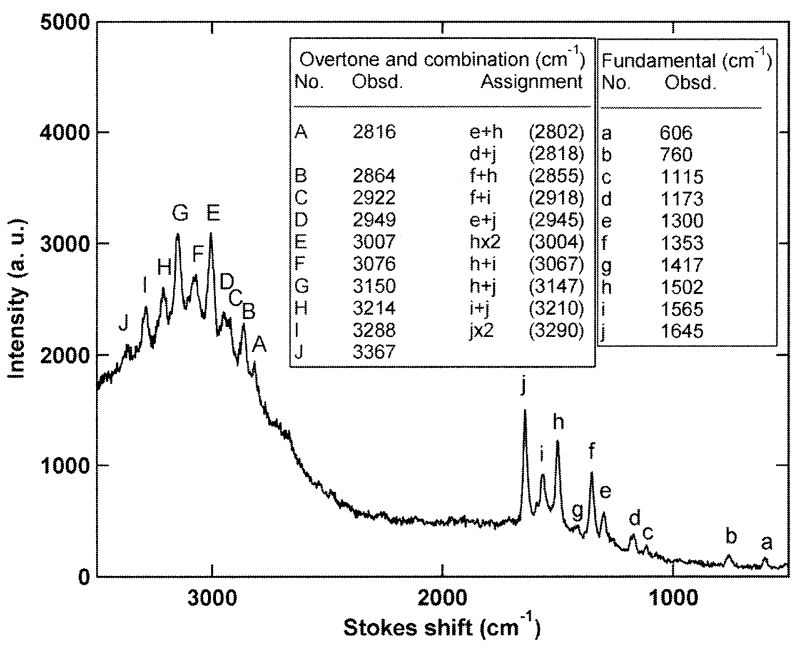

Fig. 11 SERS, inelastic scattering and emission from SERS active particles (Ag/R6G). Background signal (inelastic scattering) is explicitly observed at around $3000 \mathrm{~cm}^{-1}$ region as well as higher order modes of $\mathrm{R} 6 \mathrm{G}$, of which assignments are given in the inserted table.

着分子に適用し，表面被覆率を規定できる条件で単一分 子感度を実証し, 汎用性を確かめること, 次の段階とし て(4)電子ビームや集束イオンビームなどにより, 基板上 あるいは近接場プローブ先端に単一分子SERS感度を有す る金属ナノ構造を形成することが必要と考えられる。

\section{参考文献}

1) A. Otto, I. Mrozek, H. Grabhorn, and W. Akemann: J. Phys. Condens. Matter 4 (1992) 1143.

2) M. Kerker: Surface Enhanced Raman Scattering, SPIE, Vol. MS10, 1990.

3) J. T. Krug, G. D. Wang, S. R. Emory, and S. Nie: J. Am. Chem. Soc. 121 (1999) 9208.

4) K. Kneipp, H. Kneipp, I. Itzkan, R. R. Dasari, and M. S. Feld: Chem. Rev. 99 (1999) 2957.

5) H. Xu, J. Aizpurua, M. Käll, and P. Apell: Phys. Rev. E 62 (2000) 4318.

6) M. Michaels, M. Nirmal, and L. E. Brus: J. Phys. Chem. B 104 (2000) 11965.

7) Y. Maruyama, M. Ishikawa, and M. Futamata: Chem. Lett. (2001) 834.

8) Y. Maruyama, M. Ishikawa, and M. Futamata: J. Phys. Chem. B 108 (2004) 673.

9) M. Futamata, Y. Maruyama, and M. Ishikawa: J. Phys. Chem. B 108 (2004) 13119.

10) Y. Maruyama and M. Futamata: J. Raman Spectrosc. 36 (2005) 581.

11) M. Futamata, Y. Maruyama, and M. Ishikawa: J. Phys. Chem. B $107(2003) 7607$.

12) M. Futamata, Y. Maruyama, and M. Ishikawa: J. Mol. Struct. 735736 (2005) 75.

13) M. Futamata, Y. Maruyama, and M. Ishikawa: Vibrational Spectrosc. 35 (2004) 121.

14) M. Futamata: Faraday Discussions, in press.

15) Y. Maruyama and M. Futamata: Chem. Phys. Lett. 412 (2005) 65.

16) A. Weiss and G. Haran: J. Phys. Chem. B 105 (2001) 12348.

17) K. S. Kunz and R. J. Luebbers: The Finite Difference Time Domain Method for Electromagnetics (CRC Press, Boca Raton, 1992).

18) A. Otto: phys. Stat. Sol. (a) 188 (2001) 1455.

19) M. Futamata and Y. Maruyama: submitted.

20) D. Palik (ed.): Handbook of Optical Constants of Solids (Academic Press, 1998). 